\title{
Clinical profile of cerebral venous thrombosis in pregnancy and puerperium in South India
}

\author{
Ramasamy Sasikala, Jagan Aishwarya*, Syed Dilshath
}

Department of Obstetrics and Gynecology, Government Rajaji Hospital, Madurai Medical College, Madurai, Tamil Nadu, India

Received: 15 May 2017

Accepted: 10 June 2017

*Correspondence:

Dr. Jagan Aishwarya,

E-mail: aishupandi85@gmail.com

Copyright: () the author(s), publisher and licensee Medip Academy. This is an open-access article distributed under the terms of the Creative Commons Attribution Non-Commercial License, which permits unrestricted non-commercial use, distribution, and reproduction in any medium, provided the original work is properly cited.

\begin{abstract}
Background: Cerebral venous thrombosis (CVT) is any thrombosis occurring in intracranial veins and sinuses, which is a rare disorder affecting 5 persons per million per year with huge regional variation. Pregnancy and puerperium are the most prevalent prothrombotic states leading to cerebral venous thrombosis. The objective of this study was to analysis the clinical profile of CVT in pregnancy and puerperium.

Methods: In this prospective study, we analysed 52 consecutive patients admitted with impairment of consciousness, seizures or focal neurological deficit at our hospital. The diagnosis of CVT was confirmed by neuroimaging. Detailed history, clinical examination and laboratory investigations were carried out in all the cases and analysed.

Results: The incidence of CVT associated with pregnancy and puerperium at our Hospital was 3.9 per 1000 obstetric admissions. The age of the patients varied from 18-35 years with a maximum age incidence (77\%) in the III decade (21-30 years). The maximum incidence was during the first two weeks of puerperium (61.8\%). The most common presenting symptoms were focal or generalised seizures $(88.4 \%)$ followed by headache $(65.3 \%)$. In spite of the alarming clinical picture, recovery was rapid and remarkable. Total mortality was $15.5 \%$ (8 cases).

Conclusions: CVT is more common during the puerperium than in the antenatal period. Obstetric CVT has a more acute onset with excellent recovery when promptly diagnosed and treated.
\end{abstract}

Keywords: Antenatal period, CVT, Puerperium, Pregnancy

\section{INTRODUCTION}

Pregnancy and puerperium are well established causes of venous thromboembolism (VTE), including intracranial venous thrombosis. ${ }^{1,2}$ Cerebral venous thrombosis (CVT) is any thrombosis occurring in intracranial veins and sinuses, which is a rare disorder affecting 5 persons per million per year with huge regional variation. The prevalence of CVT in Indian population is about 4.5/1000 obstetric admissions. Several physiological changes in coagulation system render pregnancy and puerperium prothrombotic states. $^{3-7}$ The exact pathogenesis of pregnancy associated cerebral venous thrombosis is still unsettled. Hypercoaguable state during plays a vital role in the development of CVT during pregnancy and puerperium. The diagnosis of CVT is generally overlooked or delayed due to its varied clinical profile and neuroimaging signs. The widespread use of neuroimaging now allows for early diagnosis and changed our approach towards the management of the disease process. Puerperal CVT in more common in India compared to western statistics. This was probably due to reporting of many large series of obstetric CVT from India in the 70's and 80 's. ${ }^{8}$ But, due to lack of any population based study or national wide multicentric hospital based studies, the exact incidence of CVT in 
India is still not known. Hence, this study was conducted to analyse the clinical profile and prognosis of obstetric CVT in South India.

The primary objective of the study was to analyse the clinical profile of CVT in pregnancy and puerperium. The secondary objectives were to find out the incidence of cerebral venous thrombosis at Government Rajaji Hospital, Madurai and to study the importance of early diagnosis and early introduction of planned therapy.

\section{METHODS}

This prospective study was conducted at Government Rajaji Hospital, Madurai Medical College, Madurai during the period of October 2009 - October 2010.

During this period, our hospital has recorded 13,164 obstetric admissions. 52 consecutive patients admitted with impairment of consciousness, seizures or focal neurological deficit were included in the study. Informed consent was taken from the patients prior to inclusion of individuals into the study.

\section{Inclusion criteria}

Antenatal or postnatal patients admitted with complaints of

- Headache

- Impaired consciousness

- Seizures

- Focal neurological deficit.

\section{Exclusion criteria}

- Known epileptic patients

- Post partum eclampsia

- CNS infection

- Head injury.

History

A detailed history regarding age, parity, time of occurrence, mode of delivery, various symptoms were taken from close relations and also from the patients if she was conscious or taken retrospectively from her. Any past history of hypertension, DVT, PIH, thrombophilias, APLAS were elicited.

\section{Clinical Examination}

A thorough general examination and central nervous system examination was done.

\section{Investigations}

Blood and urine were sent for all investigations related to cerebral venous thrombosis like renal functions test, haematological examinations and APLA. Fundus examination and MRI with MRA/MRV were done for all patients.

The diagnosis was made by correlation of clinical features, the time of occurrence of illness and MRI with MRA / MRV scan findings.

Neurophysician opinion was obtained for all patients and was treated with anticonvulsants, antiedema measures and anticoagulants and patients were followed up till discharge from hospital or death.

\section{Statistical analysis}

The results were collected in a standardised Performa and were analysed by calculating percentages and mean values. The statistical software SPSS V.19 was used for statistical analysis.

\section{RESULTS}

The demographic details and the baseline parameters of the patients are consolidated in Table 1. The age of the patients varied from 18-35 years with a maximum age incidence $(77 \%)$ in the III decade (21-30 years).

Table 1: Baseline parameters in the study subjects.

\begin{tabular}{|c|c|c|c|}
\hline \multirow[t]{2}{*}{ Variables } & & \multicolumn{2}{|c|}{$\begin{array}{l}\text { No. of } \\
\text { patients }\end{array}$} \\
\hline & & No. & $\%$ \\
\hline \multirow{3}{*}{ Age } & $16-20$ years & 7 & 13.4 \\
\hline & $21-30$ years & 40 & 77 \\
\hline & $31-35$ years & 5 & 9.6 \\
\hline \multirow{3}{*}{$\begin{array}{l}\text { Socioeconomic } \\
\text { status }\end{array}$} & Low & 38 & 73 \\
\hline & Middle & 12 & 23 \\
\hline & High & 2 & 4 \\
\hline \multirow{2}{*}{ Population } & Rural & 36 & 66.7 \\
\hline & Urban & 16 & 33.3 \\
\hline \multicolumn{4}{|l|}{ Obstetric history } \\
\hline \multirow{2}{*}{ Parity } & Primigravida & 23 & 44.3 \\
\hline & Multigravida & 29 & 55.7 \\
\hline \multirow{4}{*}{ Time } & Antepartum & 4 & 7.6 \\
\hline & $\begin{array}{l}\text { Postpartum 3-14 } \\
\text { days }\end{array}$ & 32 & 61.8 \\
\hline & $15-28$ days & 12 & 23 \\
\hline & 28-42days & 4 & 7.6 \\
\hline \multirow{2}{*}{ Prenatal care } & Booked & 42 & 80.8 \\
\hline & Unbooked & 10 & 19.2 \\
\hline \multirow{2}{*}{ Place of delivery } & Home delivery & 4 & 8.4 \\
\hline & hospital delivery & 44 & 91.6 \\
\hline \multirow{3}{*}{ Mode of delivery } & $\begin{array}{l}\text { Following } \\
\text { abortion }\end{array}$ & 1 & 2 \\
\hline & Vaginal delivery & 35 & 73 \\
\hline & LSCS & 12 & 25 \\
\hline
\end{tabular}

The rural population was affected more than the urban population with a ratio of $2: 1$. The maximum incidence, 
32 out of 52 cases $(61.8 \%)$ were seen in the first two weeks of puerperium. CVT was commonly seen in multiparous women $(55.7 \%)$ and most of them belong to low socioeconomic status $(73 \%)$.

Table 2: Clinical profile of the patients with CVT.

\begin{tabular}{|c|c|c|c|}
\hline & Symptoms & No. & $\begin{array}{l}\text { Present } \\
\text { Series } 52 \\
\text { cases \% }\end{array}$ \\
\hline \multirow{11}{*}{ Symptoms } & Coma & 8 & 13 \\
\hline & Aphasia & 6 & 11 \\
\hline & Blindness & 4 & 7 \\
\hline & $\begin{array}{l}\text { Focal or } \\
\text { generalized } \\
\text { seizures }\end{array}$ & 46 & 88.4 \\
\hline & Paresis & 17 & 32 \\
\hline & Fever & 7 & 13 \\
\hline & Hypertension & 6 & 11 \\
\hline & Headache & 34 & 65.3 \\
\hline & Vomiting & 26 & 50 \\
\hline & Papilloedema & 8 & 15 \\
\hline & Hypotension & 1 & 1.9 \\
\hline \multirow{4}{*}{$\begin{array}{l}\text { Neuroimaging } \\
\text { findings }\end{array}$} & $\begin{array}{l}\text { Single sinus } \\
\text { thrombosis }\end{array}$ & 14 & 28 \\
\hline & $\begin{array}{l}\text { Combined sinus } \\
\text { thrombosis }\end{array}$ & 37 & 70 \\
\hline & MRI not taken & 1 & 1.9 \\
\hline & $\begin{array}{l}\text { Parenchymal } \\
\text { involvement }\end{array}$ & 23 & 44 \\
\hline \multirow{6}{*}{$\begin{array}{l}\text { Site of } \\
\text { thrombosis }\end{array}$} & $\begin{array}{l}\text { Superior sagittal } \\
\text { sinus }\end{array}$ & 34 & 65 \\
\hline & Lateral sinus & 32 & 60 \\
\hline & Sigmoid sinus & 19 & 36 \\
\hline & Straight sinus & 9 & 17 \\
\hline & $\begin{array}{l}\text { Deep cerebral } \\
\text { vein }\end{array}$ & 3 & 5 \\
\hline & $\begin{array}{l}\text { Great vein of } \\
\text { Galen }\end{array}$ & 1 & 1.9 \\
\hline
\end{tabular}

The clinical profile and the outcome are depicted in table 2 . The most common presenting symptoms were focal or generalised seizures $(88.4 \%)$ followed by headache (65.3\%). Thrombosis was the most common neuroimaging findings with combined sinus thrombosis seen in majority of the patients $(70 \%)$. The most common site of thrombosois was the superior sagittal sinus $(65 \%)$ followed by lateral sinus thrombosis $(60 \%)$.

Table 3: Final outcome in 52 cases of CVT.

\begin{tabular}{|lll|}
\hline Good outcome & $\mathbf{n = 5 2}$ & $\%$ \\
\hline Total recovery & 38 & 73 \\
\hline Mild sequel & 4 & 7.7 \\
\hline Poor outcome & & \\
\hline Severe sequel & 2 & 3.8 \\
\hline Death & 8 & 15.5 \\
\hline
\end{tabular}

Table 3 shows the final outcome of patients with CVT. Inspite of the alarming clinical picture, recovery was rapid and remarkable. 38 out of the 52 patients $(73 \%)$ recovered without any neurological disability. 4 out of 52 patients $(7.7 \%)$ were discharged with minimal residual paresis. Total mortality was $15.5 \%$ (8 cases).

\section{DISCUSSION}

A wide variety of known conditions may predispose to CVT, and their relative importance may vary with the topography. During the 1 year of observation, there were 13,164 obstetric admissions and 52 of these were admitted with CVT. This prospective observational study shows the incidence of CVT to be 3.9 per 1000 obstetric admissions. Similar results have been observed in many other Indian studies like Aniket et al, Pai et al and NIVSR cohort study. ${ }^{9,10}$ Most of the earlier case series of CVT reported from India has reported very high proportions of puerperal CVT. In 1984, Srinivasan et al, reported 135 cases of stroke in women, of whom only 6 had an arterial stroke, and the rest had a CVT. ${ }^{11}$

In present study, a much lower incidence has been reported compared to prior studies. A change in this trend in recent times has been noted mainly due to improvement in obstetric care.

Out of the 52 cases, 48 patients had delivered and 4 were in the third trimester of pregnancy. Out of the 4 antenatal cases, one had normal vaginal delivery; one died within 40 minutes of admission at 7 months of gestation and the other two recovered completely and continued pregnancy with anticoagulants. The maximum incidence, 32 out of 52 cases $(61.8 \%)$ was seen in the first two weeks of puerperium. This is correlating with Srinivasan et al and Maru A et al series. ${ }^{11,12}$ Pregnancy induces several prothrombotic changes in the coagulation system that persists at least during early puerperium. Hypercoagulability worsens after delivery as a result of volume depletion and trauma. The greatest risk period for the occurrence of CVT is in the third trimester and the first 4 postpartum weeks. ${ }^{13}$

Majority of the cases 36 out of the 52 patients $(66.7 \%)$ belonged to rural population where people lived under unhygienic conditions and were predisposed to anaemia and local traditional practice of water restriction in the peripartum period leading to dehydration. M Alexander et al in their study suggested possible role of fluid restriction practice in the causation of CVT. ${ }^{14}$ Majority of the patients in the present study were in low socioeconomic group. Prakash $\mathrm{C}$ et al in their study mentioned that reasons for its frequent occurrence in socioeconomically backward persons especially of Indian origin need to be researched. ${ }^{15}$

The incidence varied from 18-35 years with the mean age being 27.6 years. The maximum age incidence, 40 out of 52 patients $(77 \%)$ was in the III decade. CVT is more 
common in multiparous $(55.7 \%)$ than primiparous similar to studies conducted by Chopra et al. ${ }^{16}$

In contrast to the arterial stroke, which can be easily diagnosed clinically in a majority of the cases, CVT has no single pattern of presentation, and it may be difficult to diagnose it on clinical grounds alone. Clinical findings in CVT fall into two major categories: Those related to increased intracranial pressure due to impaired venous drainage; and, those related to focal brain injury from venous ischemia/infarction or hemorrhage.

In our study seizure was the most common presenting symptom seen in $88.4 \%$ of cases. According to Ferro JM et al the incidence of seizure is more in peripartum CVT. ${ }^{17}$ This justifies the higher incidence of seizure in our study as most of the cases were in the puerperal period. Out of the 46 cases, 12 patients developed status epilepticus out of which 3 cannot be revived and died within 1 hour of admission.

Headache is another most frequent symptom of CVT. The mechanism of headache is postulated to be the stretching of nerve fibers in the walls of the occluded sinus and local inflammation, as suggested by the evidence of contrast enhancement of the sinus wall surrounding the clot. In present study headache as a presenting symptom has been documented in $65.3 \%$ of cases similar to many other studies.

In our study 17 patients presented with paralysis (32\%) out of which 8 had hemiplegia right or left, 9 patients had hemiparesis similar to Pai et al and Narayan et al. ${ }^{9,10}$ Focal neurological deficit presents depending on the area involved. Thus, hemiparesis may be encountered, and in some cases of sagittal sinus thrombosis, there is involvement of bilateral lower extremities.

The incidence of coma in our study was only $13 \%$ compared to other case series from India that reported $43 \%$ to $93 \%$ of patients had an altered sensorium at presentation. ${ }^{15,18,19}$ The reason for this decrease is probably due to patients seeking medical help earlier in the recent times. ${ }^{10}$

Aphasia was present in 6 patients (11\%); fever was present in 7 cases(13\%). 2 patients presented with symptoms of psychosis. Blood pressure above 140/90 $\mathrm{mm}$ of $\mathrm{Hg}$ only in 6 cases $(11 \%)$. The fundus was normal in 44 patients but 8 patients had signs of papilloedema(15\%). Papilledema may be seen on fundoscopy in chronic cases or those with a delayed presentation but is less common in acute cases. All the above mentioned clinical profile correlated with the studies conducted by Srinivasan et al, Preter et al, Agostoni et al, Maru A et al. ${ }^{11,12,20,21}$

In this study, we found a higher frequency og thrombotic lesion (51cases) on MRI and MRA/MRV scan. Out of which 23 had parenchymal brain lesion similar to Idbaih
A studies, Cakmak S et al, SD Treadwell. ${ }^{22-24}$ Superior saggital sinus was the most common site, 34 out of 52 cases $(65 \%)$ to be involved. Combined sinus thrombosis, 37 out of 52 cases $(70 \%)$ was more common than single sinus involvement.

Management of obstetric CVT is not different from that of CVT unrelated to pregnancy. Hence it includes supportive care, seizure control, measures to lower intracranial pressure, search and treatment of possible infection. To prevent further thrombosis, anticoagulation is the preferred treatment, currently. Of the 52 cases, 49 patients were treated with heparin and only 3 people in whom heparin was used died. Use of heparin reduces the mortality as proven by similar studies like Srinivasan et al, Bousser and Ferro et al. ${ }^{11,23}$

Compared to arterial stroke CVT has favourable outcome. ${ }^{25}$ Most of our patients in the present study have recovered completely. In the past, CVT was diagnosed mainly at autopsy and was considered to be a lethal disease with a mortality ranging from 30-50\%., ${ }^{1,9}$ In present study the mortality was $15.5 \%$ due to better obstetric care, advent of newer imaging techniques and increased sensitization towards diagnosis.

\section{CONCLUSION}

Obstetric cerebral venous thrombosis most commonly presents during the puerperal period and is a major cause of stroke in young women. Diagnosis of CVT is challenging due to its wide spectrum of clinical profile and need of high index of suspicion. MRI/ MRA/MRV has revolutionized neuro diagnosis and used as first line diagnostic tool for CVT. Early diagnosis and early institution of therapy reduces the mortality of CVT in young females. Further studies done at multicentric hospital based and community level would be necessary to study underlying aetiology of obstetric CVT and result of present study replicable.

\section{ACKNOWLEDGMENTS}

Authors would like to thank all patients for their contribution without whom this study would not been possible.

\section{Funding: No funding sources}

Conflict of interest: None declared

Ethical approval: The study was approved by the Institutional Ethics Committee

\section{REFERENCES}

1. NIH Consensus Development. Prevention of venous thrombosis and pulmonary embolism. JAMA. 1986;256(6):744-9.

2. Jeng JS, Tang SC, Yip PK. Stroke in women of reproductive age: comparison between stroke related 
and unrelated to pregnancy. J Neurol Sci. 2004;221(1-2):25-9.

3. Clark P, Brennand J, Conkie JA, McCall F, Greer IA, Walker ID. Activated protein C sensitivity, protein $\mathrm{C}$, protein $\mathrm{S}$ and coagulation in normal pregnancy. Thromb Haemost. 1998;79(6):1166-70.

4. Cerneca F, Ricci G, Simeone R, Malisano M, Alberico S, Guaschino S. Coagulation and fibrinolysis changes in normal pregnancy. Increased levels of procoagulants and reduced levels of inhibitors during pregnancy induce a hypercoagulable state, combined with a reactive fibrinolysis. Eur J Obstet Gynecol Reprod Biol. 1997;73(1):31-6.

5. Cumming AM, Tait RC, Fildes S, Yoong A, Keeney S, Hay CR. Development of resistance to activated protein $\mathrm{C}$ during pregnancy. $\mathrm{Br} \mathrm{J}$ Haematol. 1995;90(3):725-7.

6. Bremme K, Ostlund E, Almqvist I, Heinonen K, Blombäck M. Enhanced thrombin generation and fibrinolytic activity in normal pregnancy and the puerperium. Obstet Gynecol. 1992;80(1):132-7.

7. Faught W, Garner P, Jones G, Ivey B. Changes in protein $\mathrm{C}$ and protein $\mathrm{S}$ levels in normal pregnancy. Am J Obstet Gynecol. 1995;172(1 Pt 1):147-50.

8. Nagaraja D, Taly AB. Puerperal cortical venous thrombosis. J Assoc Physicians India. 1993;41(7):473.

9. Pai N, Ghosh K, Shetty S. Hereditary thrombophilia in cerebral venous thrombosis: a study from India. Blood Coagul Fibrinol. 2013;24(5):540-3.

10. Narayan D, Kaul S, Ravishankar K, Suryaprabha T, Bandaru VCSS, Mridula KR, et al. Risk factors, clinical profile, and long-term outcome of 428 patients of cerebral sinus venous thrombosis: insights from Nizam's Institute Venous Stroke Registry, Hyderabad (India). Neurol India. 2012;60(2):154-9.

11. Srinivasan K. Cerebral venous and arterial thrombosis in pregnancy and puerperium. A study of 135 patients. Angiology. 1983;34(11):731-46.

12. Panagariya A, Maru A. Cerebral venous thrombosis in pregnancy and puerperium--a prospective study. J Assoc Physicians India. 1997;45(11):857-9.

13. Wilterdink JL, Easton JD. Cerebral ischemia in pregnancy. Adv Neurol. 2002;90:51-62.

14. Aaron S, Alexander M, Maya T, Mathew V, Goel M, Nair SC, et al. Underlying prothrombotic states in pregnancy associated cerebral venous thrombosis. Neurol India. 2010;58(4):555-9.

15. Bansal BC, Gupta RR, Prakash C. Stroke during pregnancy and puerperium in young females below the age of 40 years as a result of cerebral venous/venous sinus thrombosis. Jpn Heart J. 1980;21(2):171-83.

16. Banerjee AK, Varma M, Vasista RK, Chopra JS. Cerebrovascular disease in north-west India: a study of necropsy material. J Neurol Neurosurg Psychiatr. 1989;52(4):512-5.

17. Bousser MG, Ferro JM. Cerebral venous thrombosis: an update. Lancet Neurol. 2007;6(2):162-70.

18. Nagpal RD. Dural sinus and cerebral venous thrombosis. Neurosurg Rev. 1983;6(3):155-60.

19. Nagaraja D, Taly AB, Shankar SK. Simultaneous cerebral arterial and venous thrombosis. J Assoc Physicians India. 1990;38(5):325-6.

20. Preter M, Tzourio C, Ameri A, Bousser MG. Longterm prognosis in cerebral venous thrombosis. Follow-up of 77 patients. Stroke. 1996;27(2):243-6.

21. Agostoni E. Headache in cerebral venous thrombosis. Neurol Sci. 2004;25(Suppl 3):S206-210.

22. Selim M, Fink J, Linfante I, Kumar S, Schlaug G, Caplan LR. Diagnosis of cerebral venous thrombosis with echo-planar $\mathrm{T} 2 *$-weighted magnetic resonance imaging. Arch Neurol. 2002;59(6):1021-6.

23. Cakmak S, Hermier M, Montavont A, Derex L, Mauguière F, Trouillas $\mathrm{P}$, et al. T2*-weighted MRI in cortical venous thrombosis. Neurology. 2004;63(9):1698.

24. Treadwell SD, Thanvi B, Robinson TG. Stroke in pregnancy and the puerperium. Postgrad Med J. 2008;84(991):238-45.

25. Dash D, Prasad K, Joseph L. Cerebral venous thrombosis: An Indian perspective. Neurol India. 2015;63(3):318-28.

Cite this article as: Sasikala $\mathrm{R}$, Aishwarya $\mathrm{J}$, Dilshath S. Clinical profile of cerebral venous thrombosis in pregnancy and puerperium in South India. Int J Reprod Contracept Obstet Gynecol 2017;6:3124-8. 